\title{
MtDNA depletion and deletions may also have a role in myelodysplastic syndrome
}

\author{
Tuncer Cayci • Bulent Kurt • Yasemin Gulcan Kurt • \\ Emin Ozgur Akgul
}

Received: 2 April 2013 /Accepted: 28 April 2013 /Published online: 9 May 2013

(C) Springer-Verlag Berlin Heidelberg 2013

\section{Dear Editor,}

We read the article by Gupta et al. titled "Mitochondrial DNA variations in myelodysplastic syndrome" with great interest [1]. In this study, the aim of the authors is to determine the frequency and spectrum of mutations of mtDNA in patients with myelodysplastic syndrome (MDS) from Indian subcontinent. With this aim, the authors have analyzed the entire mitochondrial genome in 21 patients and 21 age- and sex-matched controls. They have amplified and sequenced the mtDNA using 24 overlapping polymerase chain reactions. A total of 37 variations have been detected in the entire mitochondrial genome from MDS patients. They concluded in their study that mtDNA mutations seem to be an important component of molecular pathology of MDS. We share the authors' scientific view and think that this study is well constructed and highly scientific.

However, we would like to express some constructive criticism. The myelodysplastic syndrome is heterogeneous group of disorders characterized by clonal proliferation of multipotent hematopoietic cells with ineffective hematopoiesis [1]. It can transform acute myeloid leukemia and

T. Cayci $\cdot$ Y. Gulcan Kurt • E. O. Akgul

Department of Biochemistry, Gulhane Military Medical Academy and Medical School, GATA, Biyokimya Anabilim Dalı, 06018, Etlik, Ankara, Turkey

\section{B. Kurt $(\bowtie)$}

Department of Pathology, Gulhane Military Medical Academy and Medical School, GATA, Patoloji Anabilim Dalı, 06018, Etlik, Ankara, Turkey

e-mail: bkurt@gata.edu.tr prognosis is usually poor [2]. We understand that the authors have considered just point mutations in mtDNA of patients with MDS. But, as known, there are three major variations of mtDNA: (1) point mutations, (2) large-scale deletions, and (3) mtDNA depletions [3]. Anyone of these variations may be the cause of mitochondrial dysfunction, production of reactive oxygen species that are clearly known to contribute in pathogenesis of cancer, and may damage DNA further. For example, Leber's hereditary optic neuropathy occurs with a point mutation. On the other hand, KearnsSayre syndrome is caused by large-scale deletions. MtDNA depletion might express as Alpers' syndrome. We wanted to add to this well-written article that the mtDNA variations other than point mutations may also have a role in the carcinogenesis of MDS.

Conflict of interest The authors declare that they have no conflict of interest.

\section{References}

1. Gupta M, Madkaikar M, Rao VB (2013) Mitochondrial DNA variations in myelodysplastic syndrome. Ann Hematol. doi: 10.1007/ s00277-013-1706-4

2. Nevruz O, Beyhan C, Guran S et al (2004) Our treatment results in patients with ANNL over 60 years old. Gulhane Med J 46(4):276279

3. DiMauro S, Bonilla E (2004) Mitochondrial encephalomyopathies. In: Engel AG, Franzini-Armstrong C (eds) Myology, vol II. McGraw-Hill, Philadelphia, pp 1623-1676 